\title{
The mango in French-speaking West Africa: cropping systems and agronomical practices
}

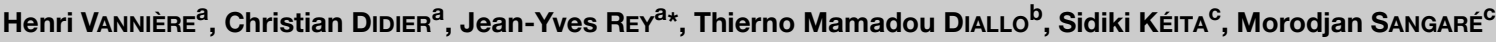

${ }^{a}$ Cirad, TA B-77/PS4,

Blvd de la Lironde,

34398 Montpellier Cedex 5 ,

France

b IER, URG, BP 30,

Bamako, Mali

${ }^{\mathrm{c}}$ Irag, CRA Bordo, BP 352,

Kankan, Guinée

${ }^{*}$ Correspondence and reprints

** Translation of the review published in Fruits, 2004, vol. 59, pp. 383-398

Received 16 June 2004 Accepted 22 October 2004

Fruits, 2007 , vol. 62, p. $187-201$ (C) 2007 Cirad/EDP Sciences All rights reserved

DOI: 10.1051/fruits:2007014 www.edpsciences.org/fruits

RESUMEN ESPAÑOL, p. 201
The mango in French-speaking West Africa: cropping systems and agronomical practices.

Abstract - Introduction. Cropping systems of the mango trees in West Africa are very varied. Each one of them developed in a specific context where the agronomical practices and the varietal composition of the orchards contribute to the diversity observed. The study undertaken should make it possible to better understand the influence of the potential outlets on the evolution of the regional mango production. Principal cropping systems. In the studied area, the main part of the mango orchards has less than 10 ha; their production is extensive and uses few inputs. They belong in majority to growers whose principal activity is centred on agriculture. Certain plantations close to 100 ha, found in Senegal or in Côte.d'ivoire, belong to exporters and profit from a technical assistance. Agronomical practices. The study of the agronomical practices used in mango orchards of West Africa made it possible to analyze the aspects of seedling production, choice of the site, installation of the orchard before plantation, plantation and maintenance of the trees, fire protection, water management, as well as the effect of the export market on the varietal choice and the varietal offer during a harvest campaign. Diseases and enemies. An inventory of the pathological problems and physiological diseases likely to devalue the production were carried out. Marketing. This part made it possible to distinguish intercontinental exports, requiring a specific harvest and conditioning organization, and the local, national and regional markets. Processing Today, the share of transformed mangos into West Africa uses only one negligible proportion of the total production. Conclusion and prospects. Beside a traditional production which presents signs of brittleness appear modern orchards. More than a necessary intensification of the orchards, a rationalization of the agronomical practices, plant health protection, fruit harvest or handling are impossible to circumvent. Downstream, the export path is confronted with a fast evolution of the exogenous regulations, based on qualitative and sanitary standards increasingly strict.

Francophone Africa / Mangifera indica / cropping systems / cultivation / plant diseases / marketing

\section{La mangue en Afrique de l'Ouest francophone : les systèmes de production} et les itinéraires techniques.

Résumé - Introduction. Les systèmes de production du manguier en Afrique de l'Ouest sont très variés. Chacun d'eux s'est développé dans un contexte spécifique où l'itinéraire technique et la composition variétale des plantations contribuent à la diversité observée. L'étude entreprise devrait permettre de mieux comprendre l'influence des débouchés potentiels sur l'évolution de cette filière horticole. Les principaux systèmes de plantation. Dans la région étudiée, l'essentiel des vergers de manguiers exploités a moins de 10 ha ; leur production est extensive et utilise peu d'intrants. Ils appartiennent en majorité à des planteurs dont l'activité principale est centrée sur l'agriculture. Certaines plantations proches de 100 ha, trouvées au Sénégal ou en Côte d'Ivoire, appartiennent à des exportateurs et bénéficient d'un encadrement technique. Les itinéraires techniques. L'étude des itinéraires techniques utilisés en vergers de manguiers en Afrique de l'Ouest a permis d'analyser les aspects de production de plants, choix du site, aménagement du verger avant plantation, plantation des et entretien des arbres, protection contre les incendies, alimentation hydrique, ainsi que l'effet du marché d'exportation sur le choix variétal et l'offre variétale au cours d'une campagne de récolte. Maladies et ennemis. Un inventaire des problèmes pathologiques et des maladies physiologiques susceptibles de dévaloriser la production a été effectué. Commercialisation. Cette partie a permis de distinguer les exportations intercontinentales, nécessitant une organisation spécifique de la récolte et du conditionnement, et les marchés locaux, nationaux et régionaux. La transformation. Aujourd'hui, la part des mangues transformées en Afrique de l'Ouest n'utilise qu'une proportion infime de la production totale. Conclusion et perspectives. A côté d'une production traditionnelle qui présente des signes de fragilité apparaissent des vergers modernes. Plus qu'une intensification des vergers, par ailleurs nécessaire, une rationalisation des pratiques agronomiques, de la protection phytosanitaire, de la récolte ou de la manipulation des fruits est incontournable. En aval, la filière d'exportation se trouve confrontée à une évolution rapide des réglementations exogènes, basées sur des normes qualitatives et sanitaires de plus en plus strictes.

Afrique francophone / Mangifera indica / système de culture / pratique culturale / maladie des plantes / commercialisation 


\section{Introduction}

Mango tree cropping systems in West Africa are highly varied, from home garden trees to mechanised, rationally designed plantations in an intensive system, via tree populations of extensive, more or less homogeneous rural systems. Each cropping system developed along a specific path and in a specific context, where the agronomical practices and varietal composition of the plantations are the essential factors contributing to the diversity observed. Not all mangoes produced in West Africa can aspire to reach all the potential outlets. The description of the crop systems and agronomical practices which we have analysed will supplement the information already published $[1,2]$, and will make for better understanding of the context of West African production. The study undertaken made for better understanding of the influence of the potential outlets - family or local consumption, local rural markets or urban markets, export, artisanal or industrial processing - on the evolution of the regional mango production.

\section{Principal cropping systems}

Besides certain mango trees found in isolation or mixed with other fruit species, most of the mango orchards cultivated in West Africa are less than 10 ha; so they are subject to extensive production systems using little input. In Upper Guinea, half of the grafted trees are planted in orchards of less than 5 ha. Plantations of around 100 ha or more are rare. In Senegal or in Côte d'Ivoire, they belong to exporters who use them to guarantee their supplies and control the quality of the product. These orchards, which are irrigated in Senegal, but little or not at all in Côte d'Ivoire, are farmed intensively, and profit from technical assistance: mineral fertiliser, phytosanitary monitoring system with disease and pest control, etc. Outside the peri-urban zones, the vast majority of orchards belong to planters whose main activity is agriculture based (plantations or annual crops) [3].

\section{Agronomical practices}

\subsection{Plant production}

Polyembryonic varieties reproduce true-totype through seeds; this is a grafting-free technique used for reproducing all the mangots and certain polyembryonic varieties such as Améliorée du Cameroun. All the rootstocks used for grafting monoembryonic varieties are grown from seeds.

Acceptable reproduction of the monoembryonic varieties can only be achieved through vegetative propagation: grafting or layering; however, layering is not used in West Africa.

Most often, grafted mango trees are produced in soil-less nurseries, in polyethylene bags. The mango trees are planted in the orchard, approximately (12 to 18) months after the rootstock is sown, i.e., (6 to 8) months after grafting. The English sideveneer grafting technique, in its simple or complicated form, is the most commonly used $[4,5]$.

Another frequently used system consists of sowing stones or planting very young rootstock directly in the orchard. In this case grafting is carried out in the field, in the second year, on every shoot present, at a height of $80-120 \mathrm{~cm}$. This provides a good setting up for the young plant, but takes up a large surface during the unproductive phase.

\subsection{Choice of site}

For logistical reasons, the location of the oldest orchards favoured proximity of a village and a means of access. With time and experience, other criteria were taken into consideration for the choice of location:

- Negative effect of wet lowland zones on fruit quality, and health problems.

- Positive effect of lateritic soils on the external colouring of mangoes and on their internal quality. These criteria are highly prized in the markets, especially the export markets. 
- Positive effect of a ground water accessible through the root system for part of the year.

As land becomes scarcer, orchards are being established at sites further from the villages, and sometimes on inferior soil.

\subsection{Installation of orchards before planting}

Besides clearing the land and cleaning up residual vegetation, often by fire, the lack of technical and financial resources which typifies the rural systems means that producers are unable to undertake plot management work. After a staking out in a more or less regular arrangement, small holes $(1 / 20$ to $1 / 10 \mathrm{~m}^{3}$ ) are opened shortly before planting. Before back filling, the soil is mixed with around $10 \mathrm{~kg}$ of farmyard manure. In the conventional systems, no mineral amendment is added. In more mechanised systems, soil preparation remains light, consisting simply of general ploughing of the plot, and sometimes crosswise ripper ploughing.

Protecting orchards from marauding livestock is a major concern. Domestic animals, particularly cattle, destroy young trees and break plants. Furthermore, twigs and fruits on the lower part of adult trees are eaten up to neck height of the cattle.

The presence of fencing is a sign of an orchard's profitability. The orchards of the Korhogo region (in Northern Côte d'Ivoire) are enclosed with hedges or with dead or live stakes, connected with barbed wire. Live cashew hedges planted very close together and connected with barbed wire have become widespread in recent years. Besides the protection provided, they offer the advantage of producing cashew nuts. Other hedges comprising spiny shrubs (Ziziphus spp., Baubinia rufescens, Acacia spp., etc.) also provide effective protection for the orchards against wandering animals. Fast growing wood species (Eucalyptus spp., Gmelina arborea, Azadirachta indica, Cassia siamea, etc.) are favoured for acting as a wind-break, while also providing firewood or stakes.

\subsection{Planting and maintenance}

There is a great variety of planting systems. In the oldest plantations, the varietal composition and plant arrangement was heterogeneous (figure 1). The use of animal draught power for ploughing forced planters to line up the trees at least in one direction (line or row). With mechanisation, two-way tree alignment has become the rule.

The distances recommended by studies at research stations have been adopted: between $8 \mathrm{~m} \times 8 \mathrm{~m}$ and $12 \mathrm{~m} \times 12 \mathrm{~m}$, they are most often $10 \mathrm{~m} \times 10 \mathrm{~m}\left(100\right.$ plants $\left.\cdot \mathrm{ha}^{-1}\right)$. However, more rarely other densities can be seen, from 45 plants $\cdot \mathrm{ha}^{-1}$ to 550 plants $\cdot \mathrm{ha}^{-1}$.

Excessive planting densities are the major defect of many orchards over 10 years old. In the absence of regular pruning and thinning, foliages entangle with each other. In this case, young twigs are pruned naturally, and the trees only bear leaves and fruit at the top. Insects and disease spread thanks to a favourable microclimate. The rare fruit produced in the middle and lower parts remains green and is often covered with sooty mould.

\subsection{Fire protection}

In the dry tropical zone, fire poses a major risk to the orchard survival. To control the development of weeds, several strategies are implemented, according to the age of the plantation:

- Annual intercrops may be planted in the first years of plantation. These crops are planted between the lines. In the savannah zone, these primarily consist of cotton, peanuts or tuber plant food crops (yams in particular), cereals (meal, sorghum and maize) or market gardening crops (figure 2). Cotton has the drawback of hosting many pests such as thrips or bugs, which may later infest the mango trees. The income from these associated crops covers all the maintenance costs of the plot, including the intercrops and mango trees.

- When the trees have attained adult age, intercrops can no longer be used due to the shade from the trees. Only certain 
Figure 1.

Heterogeneous mango orchard in West Africa: with a mixture of different ages and varieties (@ J.-Y. Rey).

(A color version of this figure is available at

www.edpsciences.org/fruits.)

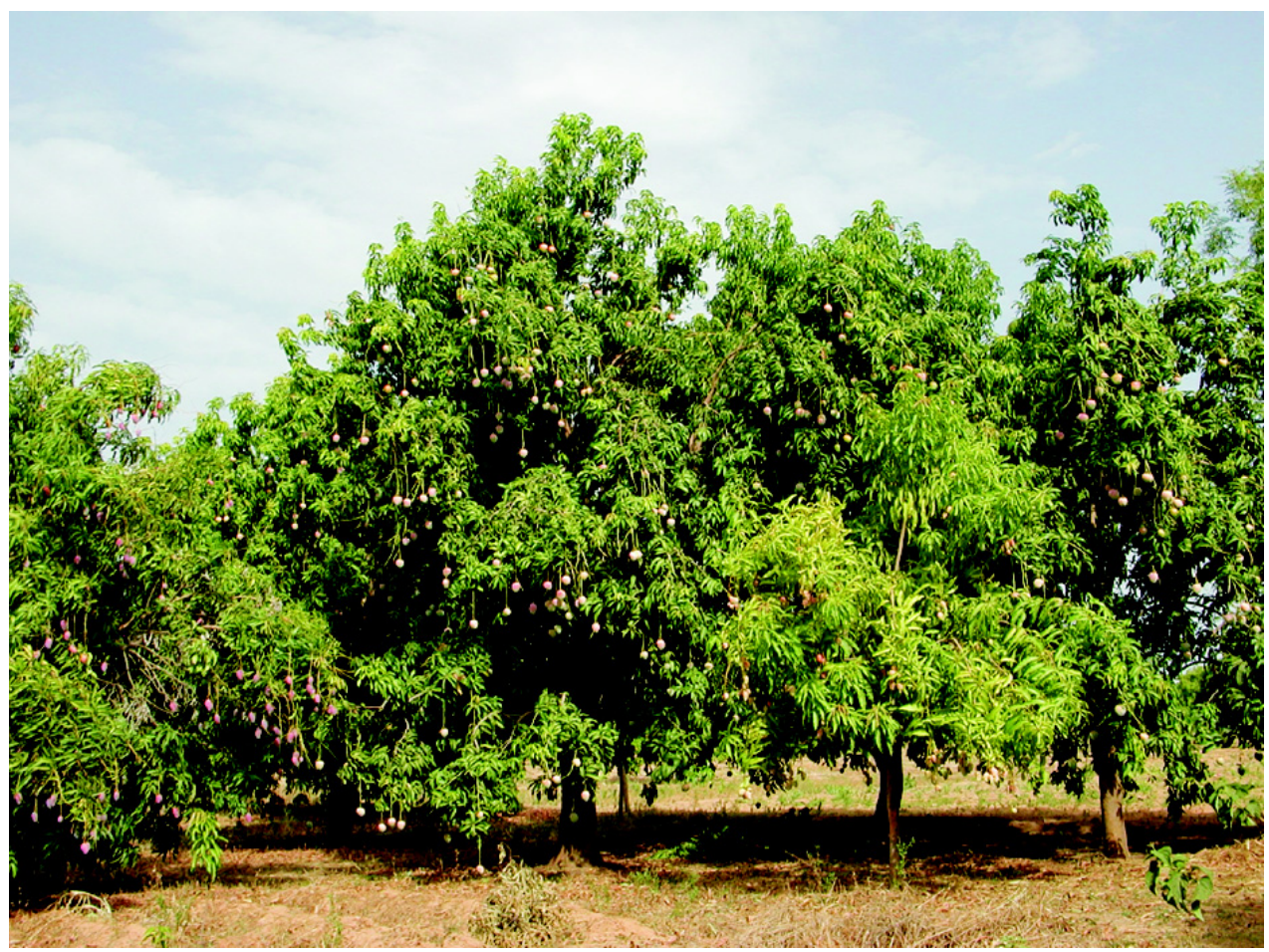

sciaphil plants, such as ginger, are sometimes grown in the shade of mango trees (in Southern Mali, for example). To prevent inflammable grasses in the dry season, weeds are controlled during the rainy season. In the large mechanised plantations, the grass reaped in the rainy season is ploughed in at the start of the dry season. In rural plantations, weeds are controlled either manually, at the start of the dry season, or by animal-draught power ploughing. This shallow ploughing causes little or no damage to the root systems.

The techniques of herbicides or temporary cover plants are too costly in terms of workload to be used except in a few big intensive plantations.

There is a strong correlation between the care taken in the orchard maintenance and the sale price of the harvested fruits.

\subsection{Water supply and irrigation}

Though irrigation of adult trees only concerns a tiny proportion of the orchards, spraying of young plants is a widely used practice.

As far as $9^{\circ}$ or $10^{\circ}$ latitude $N$, trees planted in May or June manage to go through the following dry season without excessive problems. The same does not apply for plants planted at the end of the rainy season. Beyond $10^{\circ}$ latitude $\mathrm{N}$, the dry seasons are increasingly long, and a water supply is essential in the first two years.

Water is often transported in buckets or tanks drawn by donkeys. Planters who have pumps and pipes irrigate their trees from a reservoir. To limit evaporation, a little straw is spread around the plant. However, straw increases the risk of fire and termite attack. By way of prevention, the soil between the lines must be kept completely clear [6].

When the mango trees attain sufficient development, planters prefer to reserve the water supply for more demanding fruit species (citrus, bananas, etc.). Young mango trees sometimes benefit from irrigation supplied to the intercrops (figure 2): green 
beans for export, peri-urban market garden crops, etc.

Localised irrigation systems, such as drip irrigation, are only found in a few big plantations.

\subsection{Effect of the export market on varietal choice}

Exporters first and foremost look for varieties suited to the European markets. In this context, the Kent variety is especially prized by importers. However, they have to use other cultivars because:

- the market demand covers a longer period than the time for which the Kent variety is readily available from a production area,

- in order to be profitable, a packing station must operate for a maximum period of activity. This is why the Kent variety's 2 months of production in a given production zone have to be extended using more precocious or later varieties.

This criterion of mango export period extension has greatly influenced recent varietal trends. Today, in the design of new orchards, the Kent variety primarily and the Keitt variety secondarily are included to put the plantation in a position to access the export market. To meet the demand of a lucrative market, farmers have adapted their old plantations using top grafting (figure 3). Initially, the reduction in varietal diversity related especially to non-grafted adult mangot type trees. Subsequently, varieties such as Valencia, Ruby, Zill or Palmer, less well suited to the export market, have been partially or completely top grafted.

\section{Diseases and enemies}

\subsection{Pathological problems}

Two diseases are considered to be major worldwide mango health problems: the

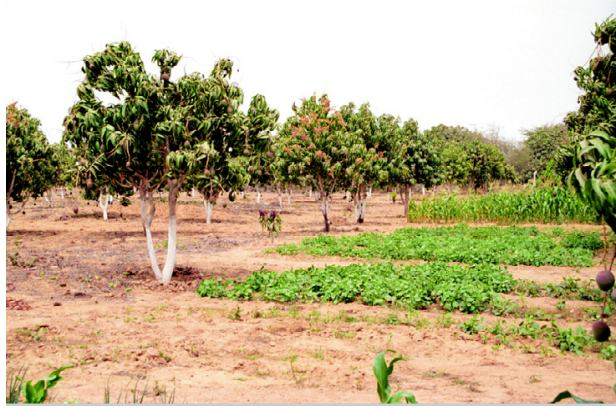

Figure 2.

Young homogeneous mango orchard in West Africa, with intercrops (@ H. Vannière). (A color version of this figure is available at www.edpsciences.org/fruits.) mango tree bacterial black spot disease caused by Xanthomonas campestris pv. mangiferae indicae [7], and a fungal disease, anthracnose, caused by Colletotrichum gloeosporioides [8-12]. The bacteriosis present in Southern and Eastern Africa has not been identified in West Africa.

Fungal diseases are more frequent in wet regions than in sahelian zones, where they have too often and systematically been incorrectly associated with diseases identified in coastal zones.

Anthracnose is very common throughout the wet zones. Its spores are water borne. In the dryer zones, contamination can only occur in the rainy season or in intense dew fall periods. Any wet microclimate will favour the appearance of the disease; this applies in particular to lowlands crossed by watercourses. On very young organs (flowers, leaves, very small fruit), which are hypersensitive, symptoms may appear very quickly. At the start of an orchard's production cycle, heavy, uncontrolled infestation may completely wipe out the potential harvest. The sensitivity of the tissues decreases with age, and contamination of developing fruits may remain latent for several weeks or months, in the form of appressoria on the

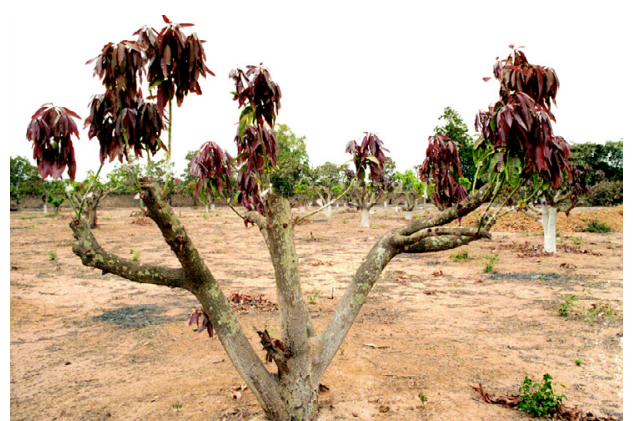

Figure 3.

Top grafted adult mango tree (C) H. Vannière). (A color version of this figure is available at www.edpsciences.org/fruits.) 


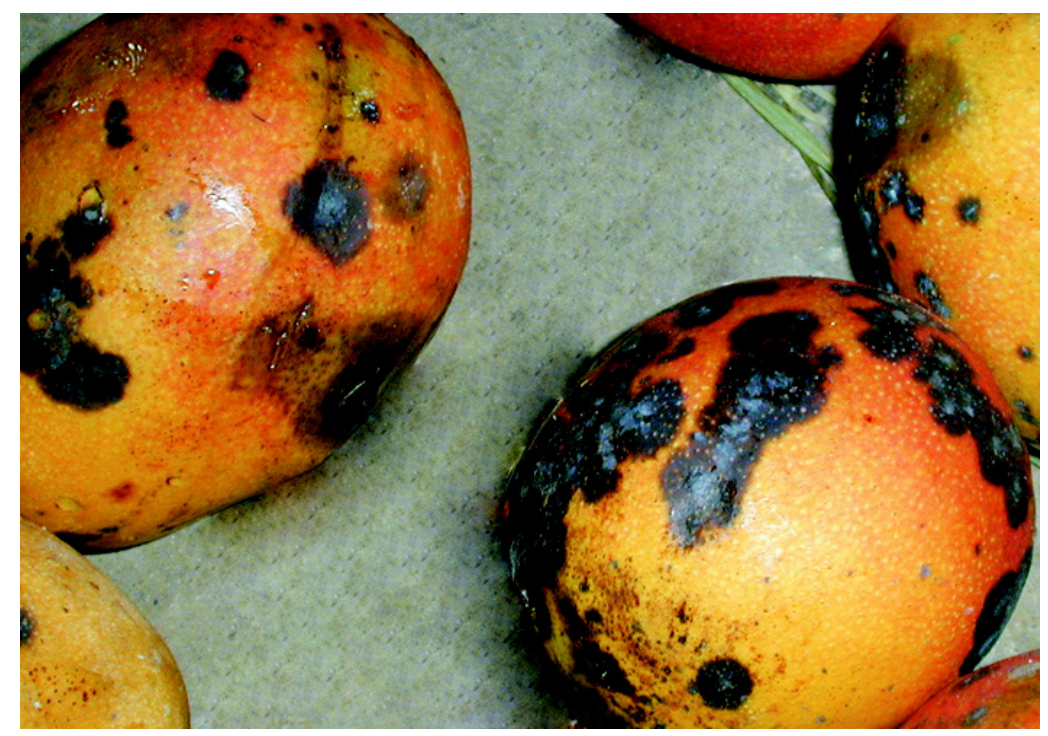

Figure 4.

Advanced stage of development of mango anthracnose: tear-streak spots (C) C. Didier). (A color version of this figure is available at www.edpsciences.org/fruits.)

Figure 5.

Advanced stage of mango stem-end rot (@ H. Vannière). (A color version of this figure is available at

www.edpsciences.org/fruits.) skin surface. Thereafter, development of the fungus is reactivated when the fruit ripens, causing rotting. Transportation of the spores in water droplets is often reflected by the presence on mangoes of blackish "streamed" linear spots (figure 4). During the harvest in the rainy season, anthracnose may contaminate fruit at a late stage, and cause the same damage.

The frequency of this disease has meant that any black spot symptom has been too systematically associated with a primary anthracnose infection [13].

Alternaria (Alternaria alternata) exhibits symptoms very similar to those caused by anthracnose: irregular shaped black spots which most often appear after harvesting. They particularly affect the skin in areas close to the pedicel, where the density of

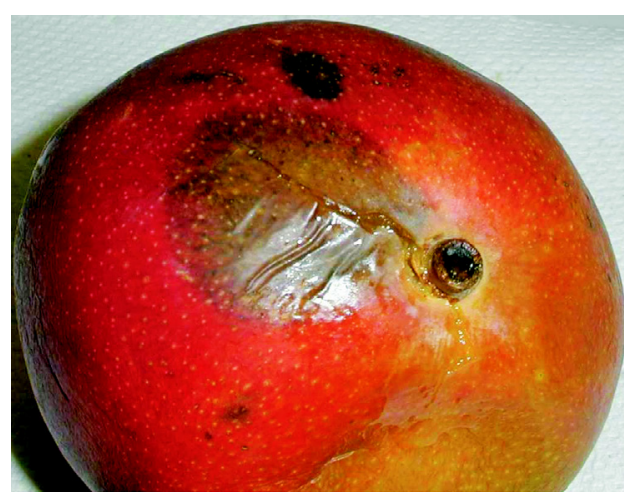

lenticels is higher. Blight has been reported mainly in regions where there is a low anthracnose rate because of a dryer and/or cooier ciimate. Ine spores are water or air borne from already contaminated organs $[12,15]$

Pathogens such as Dothiorella dominica, Phomopsis mangiferae, Lasiodiplodia theobromae (synonyms: Botryodiplodia theobromae or Diplodia natalensis), etc. [10, 12, 14] cause similar symptoms with the generic name of stem-end rot. They represent a significant proportion of contamination, and come in the form of dark spots near to the stem-end attachment. As they develop, they coalesce, forming wide, soft areas around the stem-end area. The flesh of the fruit is seriously affected. In the final phase, the rot takes on a wet appearance, known as water soak; it is common for a liquid to escape from the split skin, which then detaches easily from the flesh, with little or no adhesion (figure 5).

Oidium, Oidium mangiferae, develops white felting, which is a mycelium, on very young leaves and inflorescences; it may lead to their complete destruction. The risk of attack is all the greater if these climatic conditions are cool and slightly wet, as in high altitude regions. Abundant rain and high humidity combined with high temperatures are not favourable to the appearance of these symptoms.

Scab caused by Elsinoe mangiferae is a fungal disease which only affects the hottest and wettest production regions. Infection requires a free liquid phase (rain). Young tissues are sensitive. The symptoms and damage are especially visible in young orchards and in nurseries. On leaves, brownish to black angular spots develop, of up to approximately $5 \mathrm{~mm}$ in diameter. On young fruits, the lesions are grey and have irregular black edges. As the fruit grows, these lesions become darker in appearance and form a slightly cracked crust. The lesions, which may cover a significant part of the fruit, remain on the surface, and do not affect the flesh [12].

Other mango diseases in West Africa have been reported, such as Phoma spp. or cercosporiosis, which is also present in dry 
savannahs where it can attack the leaves in the rainy season.

Effective control of these various fungal diseases requires correct identification of the pathogen beforehand; the implementation of a control strategy includes prevention, such as early elimination of sources of inoculum in the orchard, in addition to phytosanitary treatments restricted to the risk periods (sensitive stages and rainy periods), possibly supplemented by post-harvest treatments for controlling fruit rot [13] These practices are rarely implemented in a rational way.

Cases of blight are associated with root rot, Armillaria mellea or Fomes spp. They may be observed when the plantation has been established on poorly stumped cleared woodland. Contamination can occur for several years by means of the stumps and dead roots still present in the soil.

Other blights are due to causes less easily determinable and probably fungal associations, or, in some cases, physiological diseases (X. Mourichon, pers. comm.).

\subsection{Animal enemies}

Animal enemies may be either mammals or arthropods.

\subsubsection{Mammals}

The damage caused by the transit of a herd of large wild mammals is real, but anecdotal in terms of the production zone under consideration. Damage by rodents which devour young trunks is insidious and more widespread.

\subsubsection{Arthropod pests}

Insects and, to a far lesser extent mites, contribute to damage to buds, inflorescences, stems, roots, leaves and fruits, as well as to shoots. Three groups of insects are especially damaging to mango trees: termites, fruit flies and the mango mealybug (Rastrococcus invadens).

\subsubsection{Termites}

Termites are one of the mango's worst enemies. Devouring the lateral roots and external parts of the roots, the trunk and branches, they cause many different blights. On the aboveground section, the tree gradually dries out from the extremities downwards, until the tree dies (figure O). There are no rapid, effective and safe termite extermination methods [16]. The damage to the root system is scarcely visible, and only concerns the planters when the drying out has reached an advanced stage. Pesticides commonly used against termites are those which are employed on the dominant crops in the zone, generally cotton. There are no products with the active materials in the pesticides used here approved for use in mango orchards. To fill the regulatory void, trials to specify the conditions for use of these pesticides, including study of the residue thresholds associated with their use on mango trees, started in July 2004 in Mali under the "Pesticides Initiative" Programme.

\subsubsection{Fruit flies}

Fruit flies (Tephritideae) are one of the major insect problems of mango trees in West Africa and worldwide. These species are a cause for concern by virtue of the direct damage they cause, and as quarantine insects in the main importing countries.

In West Africa's savannah zones, the most common fruit fly species is Ceratitis cosyra, which often represents over $90 \%$ of the population. Other species such as C. silvestrii, C. quinaria, C. rosa, C. ditissima, C. anonae and $C$. bremii appear late, during the rainy season. In Maritime Guinea, C. rosa is more abundant, while $C$. capitata, $C$. punctata or C. flexuosa are less common [17-19].

The flies lay their eggs in the fruits. The larvae emerging from these eggs, known as "grubs" or "maggots", feed on the fruit pulp, and dig tunnels in it (figure 7). Before the end of their larval cycle, they drop to the ground where they transform into pupae. Winged adults will later emerge from these pupae. A fruit-bearing season will see several successive generations, leading to exponential multiplication of the population. Secondary rot develops in the fruits from the egg holes or larvae tunnels, and holed fruits drop off the trees. Dropping and rot lead to the loss of many fruits. 


\section{Figure 6.}

Blight on an adult mango tree under termite attack (C J.-Y. Rey). (A color version of this figure is available at www.edpsciences.org/fruits.)

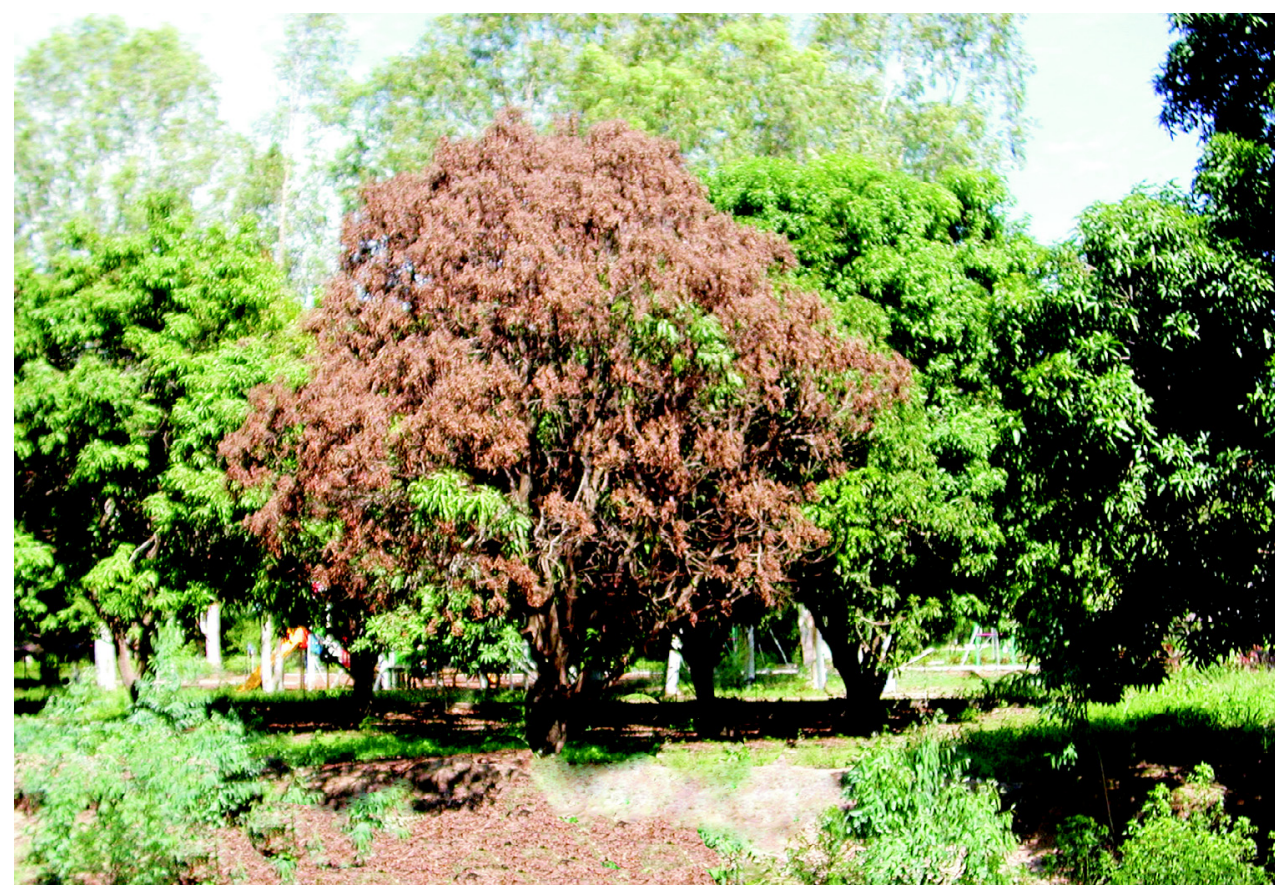

Tephritideae are classified as quarantine insects by many importer countries: the European Union, the United States, Australia, New Zealand, Japan, etc. This classification means that detection by the plant protection services of the importer country of a single live larva in a fruit will result in the destruction of the entire batch from the same source (pallet, container, etc.).

The flies primarily hole fruits close to ripeness. So the proximity of the harvest makes treatments tricky, and the presence of pesticide residue is a cause for concern in generalised treatment. For these reasons, there has been research into technique improvement. Among the various lines of investigation, monitoring fly populations by trapping (alert) associated with spot treatment (population reduction) has proved to be promising. Trapping uses sexual attractants, or parapheromones, to attract males. Beyond a certain specified weekly capture threshold, fly populations are deemed dangerous. According to the circumstances, date before harvest and level of infestation, generalised treatment or spot treatment is adopted. With spot treatment, a mixture of food attractant and insecticides is sprayed onto a few square metres of foliage per tree, without treating the fruits. The flies attracted by the attractants are killed by the associated insecticide [13].

The spot treatment technique was studied at IER (Rural Economics Institute) in Mali [17], in collaboration with CAE (Agro-enterprise centre), and at the CNRA (National Agronomy Research Centre) in Côte d'Ivoire. The IITA (International Institute of Tropical Agriculture) in Benin has conducted research into improving spreading techniques, finding effective locally produced attractants and insecticides less hazardous to human health and the environment. The spot treatment technique has given mixed results when applied to a limited surface area (a few orchards) within an infested area and/or when it is started late in a context of very high irruption or during the rainy seasons.

\subsubsection{Mango mealybug}

The mango mealybug, Rastrococcus invadens, originates from Asia. It was introduced accidentally on the coasts of Benin and Togo where, in the absence of its natural enemies, it spread very quickly. $R$. invadens has a very high reproduction capacity, secretes a viscous irritant liquid, honeydew, which runs onto the leaves and prevents 


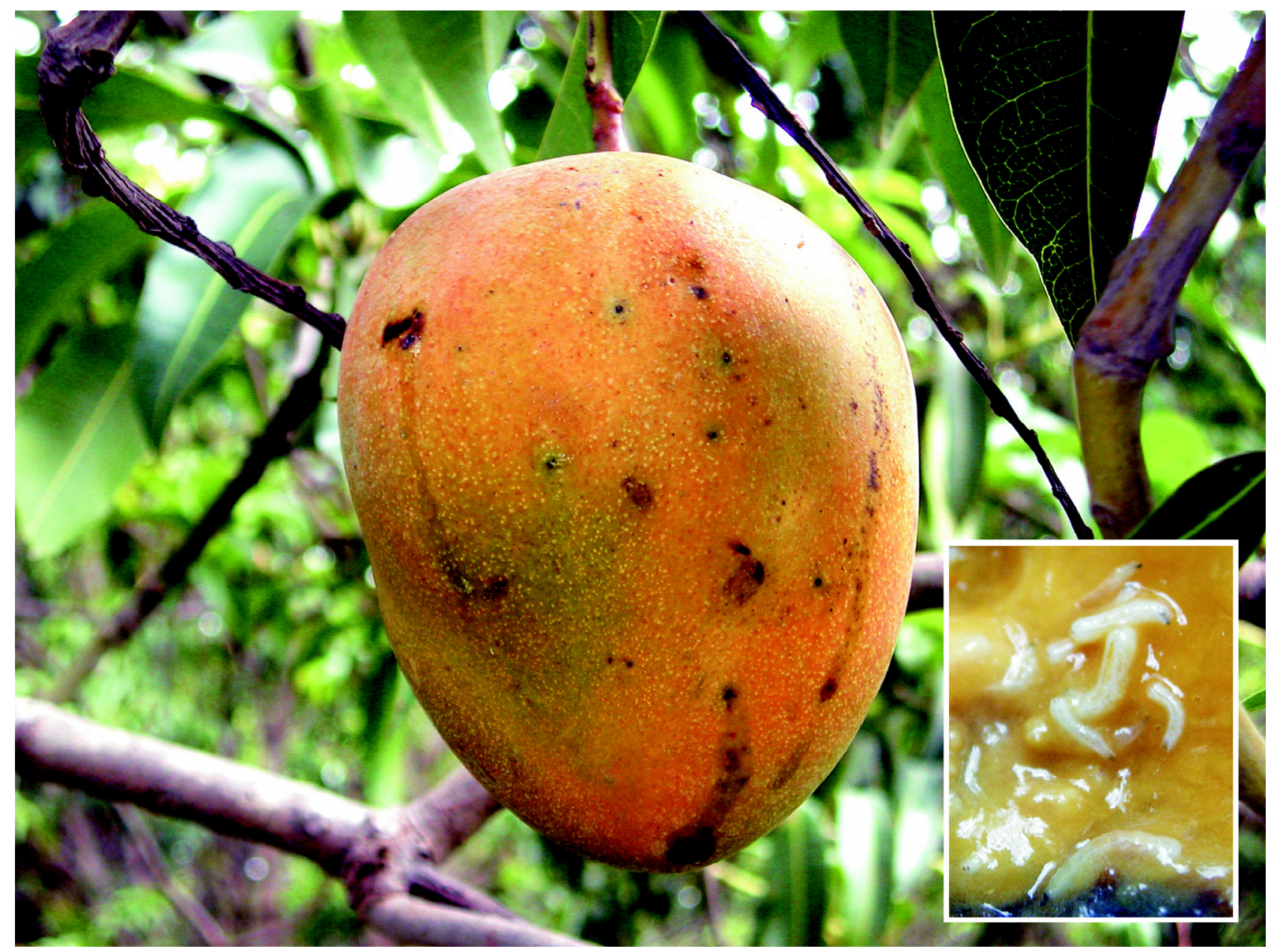

humans or animals from staying in the shade of infested trees. In the rainy season, a fungus develops on the honeydew, forming a black crust known as sooty mould on the leaf surface (figure 8). Trees infected with sooty mould do not flower and stop bearing fruit.

Biological control of $R$. invadens, first used by the IITA in Benin, consisted of introducing two parasitic Asian hymenoptera which prey on the bug. These two hymenoptera act in tandem: Gyranusoïdea tebygi preys on the bugs at the first or second larval stage and Anagyrus mangicola prefers the bugs at the second or third larval stage, and adult females [20]. This introduction proved to be particularly effective, which has meant that the bug has practically been eliminated from the coastal zone.
$R$. invadens then developed towards the North and West. N'Guetta was able to track its arrival in Côte d'Ivoire from roads out of Ghana, then its progression to the wet zones of Côte d'Ivoire, before the infestation in the dryer zones of Korhogo and the cities and orchards of the north of the country (N'Guetta $(\dagger)$, pers. comm.). The work conducted by IDEFOR (Institute of Forestry, which subsequently became the CNRA) in Côte d'Ivoire demonstrated the importance of bus stations or gates at the entry to cities as points of dispersion; vehicles which are often parked in the shade of mango trees pick up infested leaves dropping from the tree and carry them to the next stopping point, which shortly leads to the contamination of more distant mango trees or orchards [21].
Figure 7.

Mango holed by fruit flies, and close-up of larvae in the fruit (○ J.-Y. Rey). (A color version of this figure is available at www.edpsciences.org/fruits.) 
Figure 8.

Mango mealybug, Rastroccocus invadens, accompanied by the development of sooty mould on the leaf blade ( $\odot \mathrm{M}$. Gbonamou). (A color version of this figure is available at www.edpsciences.org/fruits.)

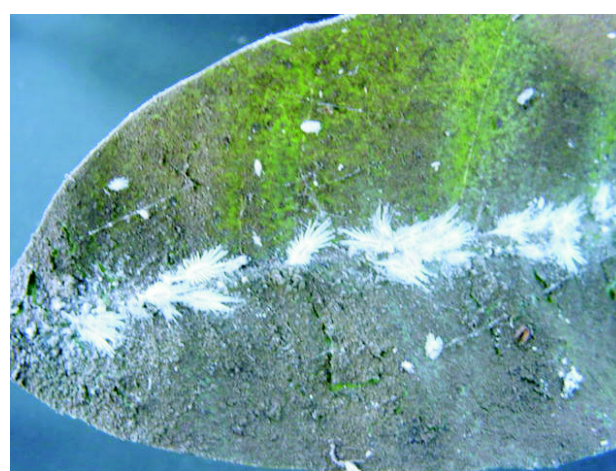

In Guinea, R. invadens first appeared in Fouta Djalon. It is currently present in the entire city of Conakry as far as kilometre 36, and is apparently present in the environs of Forécariah. It has not yet been reported in Upper Guinea. In Senegal, it is apparently present in the south of the country, where parasitoid releases have taken place; the Niayes area is still unaffected.

In Northern Côte d'Ivoire, biological control has not proved as effective as in wet zones. Studies conducted by N'Guetta and then Hala N'klo (CNRA) aimed to determine the causes of this lower effectiveness and to develop other control methods. The hypothesis of the bug and parasites development cycles being out of step was put forward, as was the effect of hyperparasites (Hala N'Klo, pers. comm.).

Since 2001, various active materials have been investigated in West Africa. Only with the final results will it be possible to recommend effective active materials which are compatible with the regulations of the various countries.

Chemical control can only be envisaged after finding the limits of natural biological control. The treatments must be applied after harvesting and before the new plant shoots sprout, so as not to endanger future flowering. In case of partial control, the treatment may be repeated (1 to 3 ) months later, at the start of the dry season. In the case of pruning, it is carried out preferably before the operation to facilitate penetration of the chemicals. Using tractors equipped with hand-held spray guns is essential to obtain sufficient wetting of the entire foliage, i.e. both sides of the leaves, as well as the inside and outside of the tree.
Pests other than those mentioned above are very rarely subject to chemical control:

- Various mealybugs and Glover's scale (Lepidosaphes gloverii), which are generally controlled by their natural enemies.

- Twig cutting chinch bugs such as Anoplocnemis curvipes, which dry out the cut twigs, while other chinch bugs attack the young leaves.

- Mole crickets, which sometimes cut young roots in nurseries, and variegated grasshoppers, Zonocerus variegates, which eat tender leaves although they prefer eating the organs of other fruit trees such as citruses.

- Many beetle species which cut through the flowering stem-ends and cause high production losses.

- Thrips, which can cause significant leaf damage.

- A whitefly, Aleurodicus dispersus, which secretes a honeydew on which spotted mould develops. Though based in the wet zones, this fly has extended its range in recent years.

- The stone weevil is also present in the wet zones. It is especially damaging to nursery plant production

\section{Physiological disorders}

\subsection{Sun scalding}

In the dry savannah, mango fruits under stress from exposure to the setting sun exhibit symptoms ranging from simple light spots on the skin to genuine necrosis (figure 9). In certain cases, the visible marks may be modest, while the internal damage is significant due to weakening of the underlying pulp. So sun scalding may cause significant losses. However, there are simple techniques capable of limiting the damage, but, since they are not well known, they are never implemented.

\subsection{Internal breakdown phenomena}

The mango is prone to develop internal physiological disorders for which no pathogen has been positively identified. For 


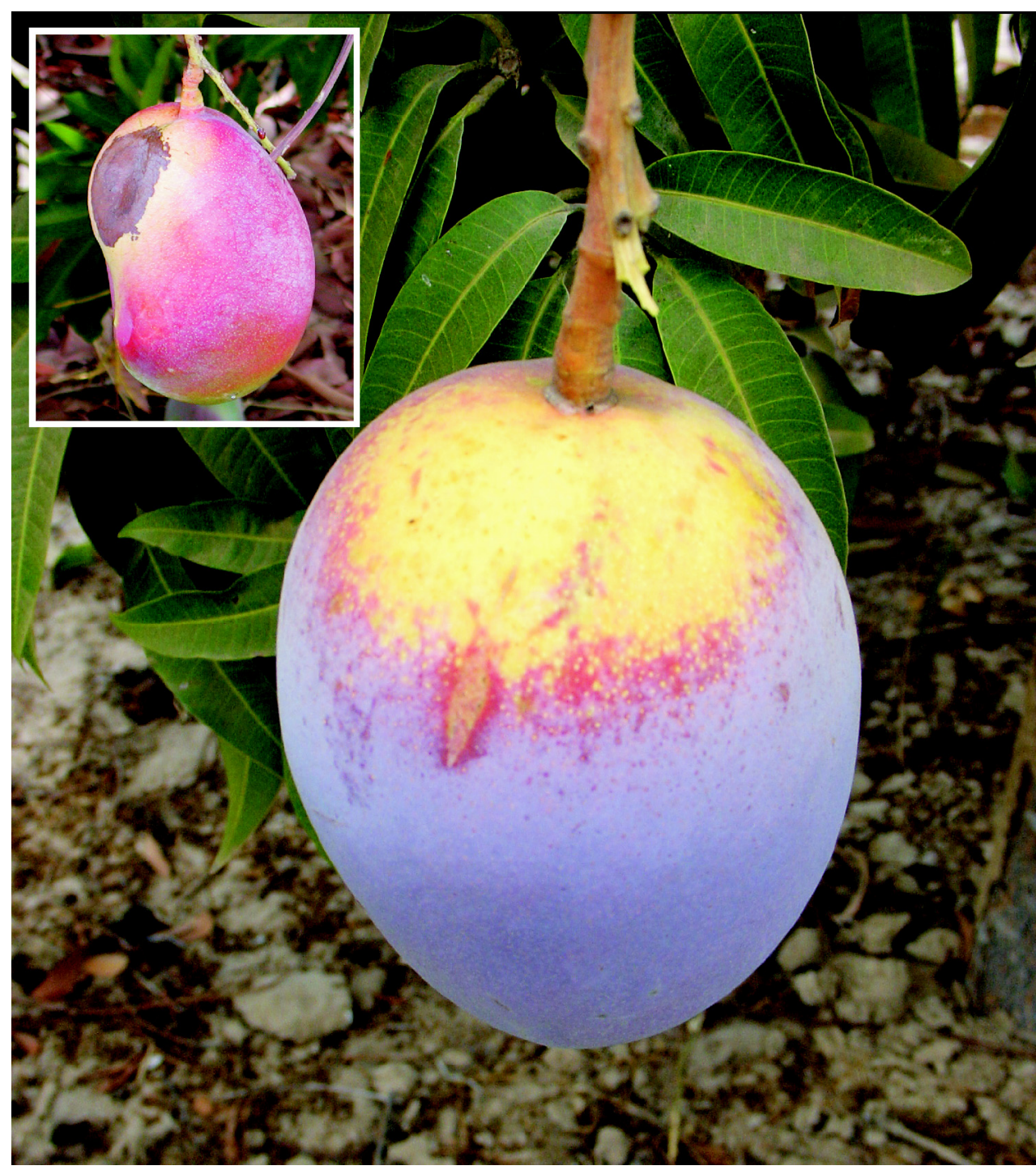

Figure 9.

Effect of sun scalding on the skin of a mango, and presentation of a severe case with necrosis (@ J.-Y. Rey, H. Vannière). (A color version of this figure is available at www.edpsciences.org/fruits.) the mango, they are grouped under the generic term internal breakdown. They are not always externally detectable, and may take on various appearances: breakdown of the apex or soft nose, jelly seed, spongy tissue, etc. These internal physiological disorders are highly damaging to fruit quality.

These breakdown phenomena result in localised softening of the pulp, sometimes accompanied by an alteration to the skin colour in the affected area. In the affected part, holes may form and the vascular tissue may turn brown. Sometimes, underneath the stem-end attachment, it is possible to observe holes surrounded by necrotic tissue (cavities). When the phenomenon reaches high intensity, the pulp starts fermenting and releases an unpleasant smell (figure 10).

The various symptoms of these physiological disorders are often associated with a varietal sensitivity: breakdown of the apex is encountered more frequently in the Smith variety, and to a far lesser extent in Keitt.

It is sometimes associated with germination of the roots in the pulp. Jelly seed and the presence of cavities are especially frequent in the Tommy Atkins variety. Little is still known about the origin of these disorders. At present, besides the varietal aspect, a calcium nutritional imbalance is often 


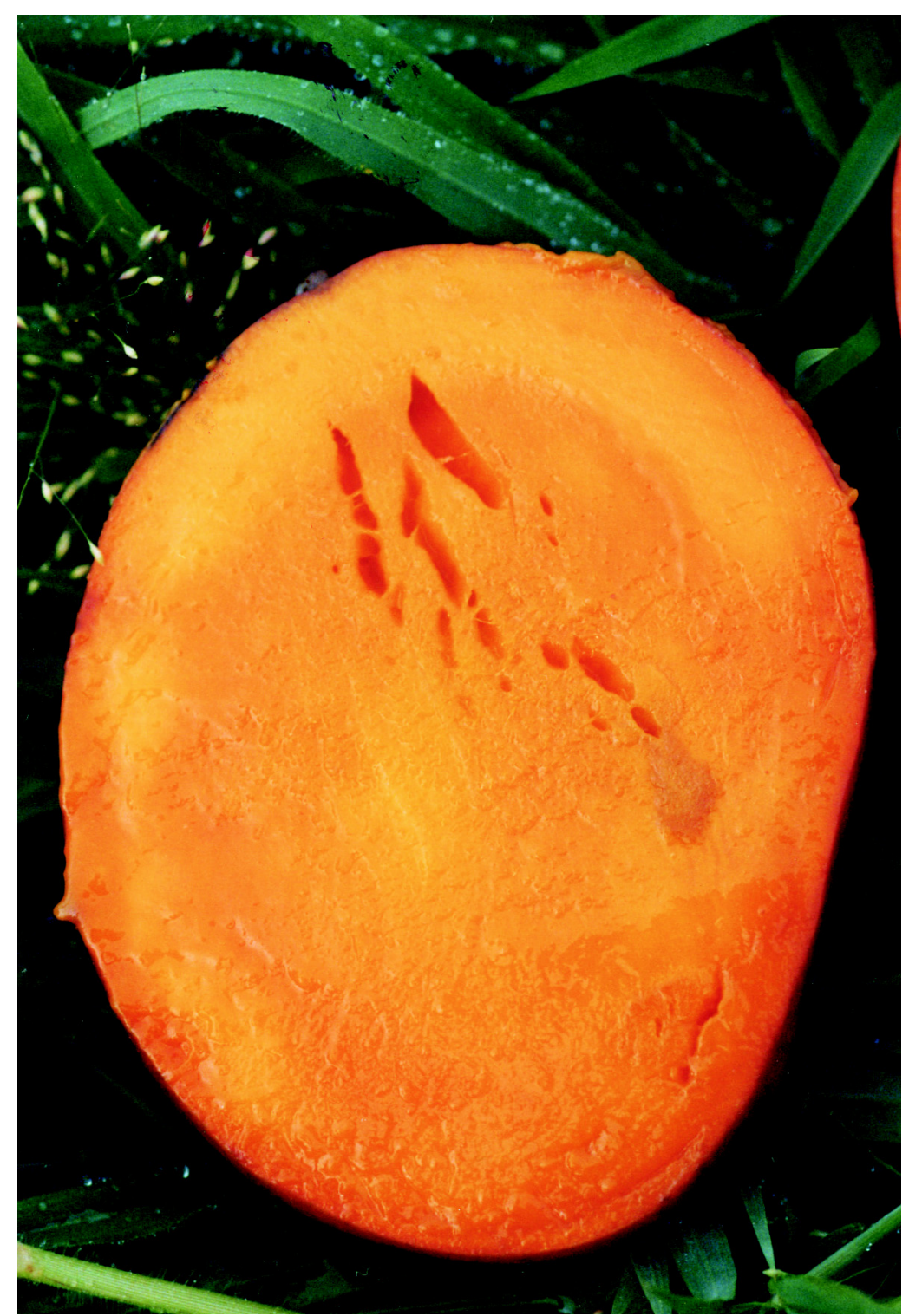

Figure 10.

Physiological disorder inside a mango: alteration of the pulp and formation of holes (C C. Haddad, Senegal). (A color version of this figure is available at www.edpsciences.org/fruits.) mentioned. The frequency of physiological disorders on the former sites of livestock pens within otherwise unaffected orchards could confirm the hypothesis of a nutritional imbalance where, besides calcium, excess nitrogen would be a factor. Other environmental factors, such as a wet microclimate, favour the appearance of physiological disorders.

\section{Marketing}

\subsection{Intercontinental exports}

In West Africa, there is a large mango production area within the region between
Bobo-Dioulasso (Burkina Faso), Bamako Yanfolila (Mali) and Tafire Dikodougou (Côte d'Ivoire).

Maritime Guinea and the Niayes region in Senegal, separated geographically and economically from the main production area, are the two main secondary production and export zones [1]. They use different transport routes and infrastructure.

The development of Senegalese exports, over $3200 \mathrm{t}$ in 2004, has been the highlight of recent years. Besides a late season production period, which has no major competition in Africa, Senegal has the advantage of regular and quick sea links with Europe (6 days).

\subsubsection{Organisation of harvest and packing}

In the majority of the production zones, the various segments of the industry have a degree of independence. The production activities, on the one hand, and the packing and export activities, on the other, are frequently separated. The fruit harvest is managed by independent agents (Mali, Burkina, Guinea), who deliver their mangoes to the packing stations, or by harvesting crews managed by an exporter (Senegal, Côte d'Ivoire). The producer is paid for all the fruit harvested by the agent or exporter, depending on the circumstances. Payment of the harvesting crews, based on export fruits, takes into account the quality of work in the harvesting and boxing process, ands also transportation to a packing station. The exporters are responsible for packing and shipment.

When collecting their fruit in rural environments, exporters made little or no investment in the production tool, the orchard. They focused their efforts on packing and marketing. For maintaining their supply sources near the small producers, they used several techniques: low interest or interest-free loans, funding and execution of mechanised work and/or phytosanitary treatment requiring major financial resources (pesticides, treatment equipment). This system of fragmented responsibility was not without drawbacks, in particular creating relationships of dependence between operators of 
the various industry segments. By virtue of the supply evolving to adapt to exporter demand, these relationships are changing, becoming more rational. This will make for easier implementation of an integrated "quality" approach complying with the new regulations [fruit traceability, adhering to the maximum residue limits (MRL), food safety, effective control of diseases and quarantine pests, etc.].

\subsubsection{Economic impacts of exports}

Although exports represent a small proportion of total production, their economic and social impact is very high. For a small producer, exports are a source of added value, since in this case mangoes are bought at six to eight times the local market price. The proximity or distance of a large city (Dakar for instance) affects prices, driving them up or down respectively. Additional distance means greater losses and transportation costs. The inherently less expensive mangoes harvested in "peripheral" zones (in Upper Guinea, for example) only come onto the market in years when there is a shortfall in overall production.

The guarantee of payment associated with export is also an advantageous aspect. For example, while the agents associated with Guinean exporters pay cash, the dealers on the local market buy fruit on credit, without a real guarantee of payment.

At regional and national level, the economic impacts are significant. The industry has led to the creation of tens of thousands of jobs from the orchards to the packing stations, and all the related activities. In Northern Côte d'Ivoire, from 1992 to 2002, the economy of an entire region was revitalised by the growth in exports. This activity is redistributing revenue in rural areas, over $0.5 € \cdot \mathrm{kg}^{-1}$, to the producer and local labour. In spite of enormous difficulties, Côte d'Ivoire's export levels in 2003 only dropped $35 \%$ from the previous year. This is a good illustration of the importance of these exports for a significant proportion of the population.

The positive impact of exports is watered down further away from the packing centres. It is in their vicinity that the most mod- ifications in practices can be observed: varietal reconversion, enclosure of orchards, soil maintenance, intensification of crop techniques, orchard disease and pest protection, etc.

\subsection{Local, national and regional markets}

The majority of mangots and some of the mangoes are consumed locally within family circles or sold ready to eat in village or nearby urban markets. A significant proportion of fruit is sold ripe, but still firm so as to withstand transportation. The fruit produced within a strip between nine and thirteen degrees latitude north is shipped in two directions:

- to the southern cities, especially in coastal countries where the main cities are ports,

- to the northern cities, such as Mopti or Gao, or neighbouring countries: Mauritania, Niger, etc., if the road network permits.

Prices are set per fruit or per box, since it is easier to count the fruit than weigh it. The prices vary according to the variety, the fruit calibre, the production period, the customer's qualitative judgement and the supply and demand on the market. Fruit can be transported in containers such as baskets, cardboard cases, etc. or in bulk in lorries to the end markets. Transportation, marketing and losses make up the primary costs. The purchase price from the producer sometimes makes up a derisory part of the final cost price.

\section{Processing}

In Africa, many factories were established for production of ready-for-consumption pulp or juice. At one time or another, every country had them, but very few managed to last in the long term. That is why the last two decades have seen a change of direction. Projects have turned towards small units, producing juice and jams, often managed by groups of women. The production of dried slices, generally produced from mangoes 
with the organic fruit label, is a growth activity.

We can note that the proportion of processed fruit is only a tiny part of total production.

\section{Conclusion and prospects}

In various regions of West Africa, since the introduction of grafted mangoes, mango plantations have experienced spectacular growth, mainly in the dry savannah zone.

Mango production for intercontinental export has experienced high growth in the savannah zones where health problems are not as great as in the wet zones. For the latter regions, varietal selection, the first step in development, must be based on different rational criteria.

Rural mango tree plantations used as space fillers have other assets besides their durability: the characteristics of territory markers and creation of capital eventually generating profit. Mango plantations were often established without a specific commercial objective, and have been harnessed within a farming system with a similar harvest time. Since then, the mango industry has seen contrasting changes, where the influence of the export outlet, whether real or potential, has been the deciding factor.

Alongside conventional production which is exhibiting signs of fragility (uncertain outlets, low qualitative and quantitative production level, high losses, low technology levels and limited margins, etc.), modern orchards are appearing, in the case of Senegal within diversified fruit farms. Above intensification of the orchards, which is also necessary, rationalisation of agronomical practices, of phytosanitary protection, harvesting and fruit handling, etc. is essential. Further downstream, the export industry is confronted with rapid changes in the external regulations, based on increasingly stringent quality and health standards, and subject to more frequent checks.

Will all operators, producers and exporters be able to meet this challenge?

Producing merchandise satisfying the most advanced quality characteristics alters the breakdown of the added value of the end product. This reality needs to be taken into consideration in the discussions taking place in the industry, while going beyond excessively narrow technical solutions. To a lesser extent and with a short delay, access to West Africa's big city markets will require a comparable change. The development projects of the "mango" industry will need take into consideration all of these thoughts in a broad context, with the objectivity required to provide sustainable solutions, which are satisfactory for all the players and for the overall viability of the industry.

\section{References}

[1] Rey J.Y., Diallo T.M., Vannière H., Didier C., Kéita S., Sangaré M., The mango in Frenchspeaking West Africa, Historical synthesis, Fruits 61 (4) (2006) 281-289 [translation of a French article published in Fruits 59 (3) (2004) 121-129].

[2] Rey J.Y., Diallo T.M., Vannière H., Didier C., Kéita S., Sangaré M., The mango in Frenchspeaking West Africa: varieties and varietal composition of the orchards, Fruits 62 (1) (2007) 57-73 [translation of a French article published in Fruits 59 (3) (2004) 191-208].

[3] Charrier D., Bambara O., Le manguier dans le département de Korhogo (Côte d'Ivoire), Fruits 42 (6) (1987) 361-383.

[4] Furon V., La multiplication du manguier au Sénégal, Fruits 21 (4) (1966) 189-193.

[5] Mulat B., Le greffage du manguier, Fruits 14 (5) (1959) 219-223.

[6] De Laroussilhe F., Le manguier, Ed. Maisonneuve \& Larose, collection Techniques agricoles et productions tropicales, Paris, France, 1980.

[7] Manicom B.Q., Pruvost O.P., Mango diseases caused by non fungal agents: bacterial black spot, in: Ploetz R.C. (Ed.), Compendium of tropical fruit diseases, APS Press, St Paul, USA, 1994, 41-42.

[8] Brun J., L'anthracnose du manguier en Guinée, Fruits 6 (11) (1951) 475-476.

[9] Mourichon X., Anthracnosis on mango, Report on a mission in Ghana, Int. doc., Irfa, Montpellier, France, 1992.

[10] Mourichon X., Mission Guinée. Appui en pathologie végétale: filière fruits de l'Irag, Doc. int., Cirad/Flhor, Montpellier, France, 1995, 32 p. 
[11] Ploetz R.C., Mango diseases caused by fungi: anthracnosis, in: Ploetz R.C. (Ed.), Compendium of tropical fruit diseases, APS Press, St Paul, USA, 1994, 35-36.

[12] Laville E., Mangue, in: La protection des fruits tropicaux, Cirad-Coleacp (Éds.), Paris, France, 1994, 131-138.

[13] Anon., Technical itinerary mango, "Pesticide Initiative" Programme (PIP), Coleacp, Brussels, Belgium, 2005, $49 \mathrm{p}$.

[14] Alabi R.O., Disease of mango fruits caused by Dothiorella dominicana, Dep. Biol. Sci., Univ. Llorin, Nigeria, 22 (1), 1986, 21-25.

[15] Prusky D., Mango diseases caused by fungi: Alternaria rot, in: Ploetz R.C. (Ed.), Compendium of tropical fruit diseases, APS Press, St Paul, USA, 1994, 34-35.

[16] Logan J.M.W., Cowie R.H., Wood T.G., Termite (Isoptera) control in agriculture and for- estry by non-chemical methods: a review, Bull. Entomol. Res. 80 (1990) 309-330.

[17] N'Guetta K., Inventaire des insectes de fruits récoltés dans le Nord Côte d'Ivoire, Fruits 49 (1994) 5002-503.

[18] Vayssières J.F., Kalabane S., Inventory and fluctuations of catches of Diptera Tephritidae associated with mangoes in Coastal Guinea, Fruits 55 (2000) 259-270.

[19] Vayssières J.F., Sanogo F., Noussourou M., Inventaire des espèces de mouches des fruits (Diptera: Tephritidae) inféodées au manguier au Mali et essais de lutte raisonnée, Fruits 59 (1) (2004) 3-16.

[20] Moore D., Cross A.E., Biological control of the fruit tree mealybug, Rastrococcus invadens Williams; Single or multiple introduction? Acta Hortic. 341 (1993) 433-439.

[21] N'Guetta K., Rapport d'activité de recherche, Doc. Int, Idefor-Dfa, Côte d'Ivoire, 1998.

\section{El mango en África occidental francófona: sistemas de producción e itinerarios técnicos.}

Resumen - Introducción. Los sistemas de producción del mango en África occidental son muy diversos. Cada sistema corresponde y se ha desarrollado en un marco concreto en donde el itinerario técnico y la composición varietal de las plantaciones contribuyen a la diversidad observada. Este estudio debería permitir comprender mejor la influencia de las potenciales salidas en la evolución de este sector hortícola. Los principales sistemas de plantación. En la región estudiada, la mayor parte de las huertas de mangos explotadas tiene menos de 10 ha; su producción es extensiva y utiliza pocos insumos. Suelen ser propiedad de cultivadores cuya actividad principal se centra en la agricultura. Algunas plantaciones de cerca de 100 ha, encontradas en Senegal o Costa de Marfil, pertenecen a exportadores y disponen de apoyo técnico. Los itinerarios técnicos. El estudio de los itinerarios técnicos utilizados en plantaciones de mangos en África occidental permitió analizar los aspectos de producción de plantones, elección del sitio, preparación de la huerta antes de la plantación, plantación y mantenimiento de los árboles, protección contra incendios, alimentación hídrica, así como el efecto que tiene el mercado de exportación en la elección y la oferta varietal durante una campaña de cosecha. Enfermedades y plagas. Se efectuó un inventario de los problemas patológicos y enfermedades fisiológicas que pueden devaluar la producción. Comercialización. Este apartado permitió diferenciar las exportaciones intercontinentales, que necesitan una organización específica de la cosecha y del acondicionamiento, y los mercados locales, nacionales y regionales. La transformación. Hoy día, los mangos transformados en África occidental representan tan sólo una proporción ínfima de la producción total Conclusión y perspectivas. Junto a una producción tradicional que da muestras de debilidad aparecen modernas plantaciones frutales. Más que una intensificación de las huertas, por otra parte necesaria, es necesario acometer la racionalización de las prácticas agronómicas, la protección fitosanitaria, la cosecha y la manipulación de la fruta. En el extremo inferior del circuito, el sector de exportación se encuentra enfrentado a una evolución rápida de las legislaciones exteriores, basadas en requisitos sanitarios y de calidad cada vez más estrictos.

Africa de habla francesa / Mangífera índica / sistemas de cultivo / cultivo / enfermedades de las plantas / mercadeo 